\title{
Pesticide Leaching from Agricultural Fields with Ridges and Furrows
}

\author{
Minze Leistra • Jos J. T. I. Boesten
}

Received: 18 December 2009/Accepted: 4 March 2010/Published online: 30 March 2010

(C) The Author(s) 2010. This article is published with open access at Springerlink.com

\begin{abstract}
In the evaluation of the risk of pesticide leaching to groundwater, the soil surface is usually assumed to be level, although important crops like potato are grown on ridges. A fraction of the water from rainfall and sprinkler irrigation may flow along the soil surface from the ridges to the furrows, thus bringing about an extra load of water and pesticide on the furrow soil. A survey of the literature reveals that surface-runoff from ridges to furrows is a well-known phenomenon but that hardly any data are available on the quantities of water and pesticide involved. On the basis of a field experiment with additional sprinkler irrigation, computer simulations were carried out with the Pesticide Emission Assessment at Regional and Local scales model for separate ridge and furrow systems in a humic sandy potato field. Breakthrough curves of bromide ion (as a tracer for water flow) and carbofuran (as example pesticide) were calculated for $1-\mathrm{m}$ depth in the field. Bromide ion leached comparatively fast from the furrow system, while leaching from the ridge system was slower showing a maximum concentration of about half of that for the furrow system. Carbofuran breakthrough from the
\end{abstract}

M. Leistra $(\bowtie) \cdot$ J. J. T. I. Boesten

Alterra, Wageningen University and Research Centre,

P.O. Box 47, 6700 AA Wageningen,

The Netherlands

e-mail: minze.leistra@wur.nl

J. J. T. I. Boesten

e-mail: jos.boesten@wur.nl furrow system began about a month after application and increased steadily to substantial concentrations. Because the transport time of carbofuran in the ridge soil was much longer, no breakthrough occurred in the growing season. The maximum concentration of carbofuran leaching from the ridge-furrow field was computed to be a factor of six times as high as that computed for the corresponding level field. The study shows that the risk of leaching of pesticides via the furrow soil can be substantially higher than that via the corresponding level field soil.

Keywords Bromide ion - Carbofuran - Computer model $\cdot$ Groundwater $\cdot$ Insecticide $\cdot$ Potato crop $\cdot$ Sandy soils $\cdot$ Simulation model

\section{Introduction}

The evaluation of the risk of pesticide leaching from agricultural soils to groundwater is an important part of the registration procedure in some parts of the world. Research data submitted in the framework of the evaluation encompasses both experiments (e.g. laboratory, lysimeters, field) and computer simulations for field scenarios (e.g. FOCUS 2000; Boesten 2004). In almost all pesticide leaching experiments (e.g. lysimeters, fields), the soil surface is quite level (no meso- and macro-depressions). In the computer simulations, the soil surface is nearly always assumed to be level. A common assumption in the evaluations 
is that water flow and substance transport in soil are rather uniform.

Potatoes are an important crop in the temperate regions of Europe and North America and in various other parts of the world (Huaccho and Hijmans 1999). The acreage in the European Union is $2.1 \times 10^{6}$ ha (Eurostat 2009). Potatoes serve as an important example of a crop grown on ridges/beds in the field, built up with soil material from the furrow strips. Part of the precipitation (rainfall, sprinkler irrigation) may flow from the ridges to the furrows, resulting in additional water infiltration in the latter. Pesticides sprayed on the soil and plant surfaces may be washed down with the precipitation water and thus lead to an extra load of the furrows. Thus, there is a risk that the furrows receive both more pesticide and precipitation water than the soil surface of a corresponding level field. This may increase the risk of pesticide leaching from the furrows to groundwater, as compared to the leaching from a level field. In general, localised water flow and pesticide transport in soil increase the risk of the leaching of residue to groundwater and tile-drain water discharged to water courses (Leistra 1985; Kung 1990a; Flury 1996). Then the pesticide bypasses much of the soil matrix, resulting in reduced adsorption and limited time for transformation in the upper soil zone with highest bioactivity.

Research data on water flow and substance transport in agricultural fields with ridges and furrows are very scattered. Therefore, this study begins with a survey of the literature data. The emphasis here is on regularly cultivated sandy soils (humic and/or loamy) without clear shrinkage cracks, biopores or blocky structures. Fields with sandy soils (e.g. European Soil Bureau Network 2005) are used on a large scale for growing potatoes and other crops on ridges/beds with furrows in between. Further, these soils are found on a large scale in areas where phreatic groundwater is pumped up for drinking water supply.

The second part of our study deals with the simulation of water flow and substance transport in a potato field with humic sandy soil, using the Pesticide Emission Assessment at Regional and Local scales (PEARL) model for pesticide behaviour in soil-plant systems. Ridge and furrow systems are distinguished in the simulations. The systems are derived from the experimental field study described by Leistra and Boesten (2008). Bromide ion serves as a tracer for water flow, and the insecticide carbofuran serves as example pesticide. The results are discussed in terms of the breakthrough curves of the substances at 1-m depth in the sand subsoil. The factors causing the differences in leaching between inert tracer and pesticide and between the ridge and furrow systems are discussed. The leaching from the two systems is compared with the leaching computed for the corresponding level field system (without ridges and furrows).

\section{Survey of Literature Data}

\subsection{Functions of the Ridge Tillage System}

Ridges are prepared to improve the plant root environment (Kouwenhoven 1978; Benjamin et al. 1990). The lower soil moisture contents and higher soil temperatures of the ridges in spring, as compared to those for a level field, promote crop emergence. In wet periods, potatoes in ridges are less vulnerable to decay due to water logging. Using furrows as driving paths, the loose structure in the ridges is maintained, and damage to the tubers is minimised. Ridges provide room for the expansion of the growing tubers. Further, mechanical harvesting of potatoes from ridges (lifting by the shares) is comparatively easy.

\subsection{Water Flow}

Water from rainfall and sprinkler irrigation can flow along the soil surface from the ridges to the furrows. In various studies, the wetting of the ridge and furrow soils by rainfall and sprinkler irrigation was measured, e.g. by using a grid of time-domain reflectometry probes. At comparatively high precipitation rates, the soil in the ridges was measured to be wetted poorly (Robinson 1999; Starr et al. 2005; Keizer et al. 2007; Cooley et al. 2007). To the contrary, rather high volume fractions of water were measured in the furrow soil, which was explained as coming from water flowing from the ridges. Such surface flow of water can be expected to be promoted by the often water-repellent character of a dried sandy top layer (Robinson 1999; Keizer et al. 2007).

After emergence of the potato plants, stemflow of precipitation water through the canopy leads to local infiltration in the soil around the stems. Stemflow of water from the potato plants was measured by 
collecting water via funnel-shaped collars around the stems (Saffigna et al. 1976). In an erect crop (around 3 months after emergence), a substantial percentage of the irrigation water (e.g. $14 \%$ to $46 \%$ ) was collected as stemflow. The stemflow of water in potato crops was measured by Jefferies and MacKerron (1985) in 2 years, in an erect crop at 1.1 to 2.3 months after emergence. Stemflow was measured to range from $17 \%$ to $87 \%$ of the above-crop precipitation (rainfall + sprinkler irrigation). The percentage of stemflow was found to be higher as precipitation intensity was lower. Stemflow is expected to decrease later in the growing season due to subsidence of the canopy (Cooley et al. 2007).

Some observations were reported on the transfer of water and soil from the ridges to the furrows. The impact of the drops from rainfall and sprinkler irrigation caused surface sealing of sandy soils, which drastically reduced the rate of water infiltration into potato ridges (Agassi et al. 1989; Agassi and Levy 1993). The water flowed along the soil surface from the ridges to the furrows, eroding soil from ridges and depositing a sediment layer in the furrows. Runoff from the ridges decreased in the course of the growing season, when a considerable amount of the precipitation water was intercepted by the crop canopy. Dekker and Ritsema (1996) measured soil moisture contents in the humic sandy soil of a field with potatoes grown on ridges. A rain shower $(20 \mathrm{~mm})$ and sprinkler irrigation $(30 \mathrm{~mm})$ wetted only part of the ridges (mainly by stemflow), while the furrows were wetted quite well. The sprinkler irrigation of $30 \mathrm{~mm}$ (at $18 \mathrm{~mm} \mathrm{~h}^{-1}$ ) even resulted in a temporary ponding of the furrows.

Pesticides sprayed on a crop can be partly washedoff by rainfall and sprinkler irrigation (Leistra 2005). It can be expected that local differences in pesticide load of the soil run parallel to the differences in water supply: highest pesticide load of the soil on places where water supply is also highest.

\subsection{Visualisation of Flow Paths with Dyes}

Two fields with loamy sand soil grown with potatoes on ridges were sprinkler-irrigated, and the resulting water flow was studied (Saffigna et al. 1976). Water infiltration into the soil was visualised by spraying a water-soluble dye on the soil surface. There was a maximum in water infiltration into the soil around the base of the potato stems due to stem flow. Local wetting of the ridges was confirmed by tensiometer measurements of moisture pressure. Another maximum in infiltration was observed to occur in the furrows. Water surface-flowed from the ridges to the furrows, especially between the potato plants on the ridges.

Dyes were applied to the soil of a potato field on the Central Sand Plain of Wisconsin (Kung 1988). A green dye was applied to the centre of the ridges, while a red dye was applied as a band to the bottom of the furrows. Rainfall was supplemented by sprinkler irrigation. At potato harvest (2.7 months after the start of the applications), the green dye in the ridge soil had moved to a depth of 0.7 to $0.9 \mathrm{~m}$. The red dye in the furrow soil had moved to $1.1-$ to $1.4-\mathrm{m}$ depth. Unfortunately, no observations on the flow of water at the soil surface were reported.

\subsection{Transport of Anion}

Kung (1990b) reported about a field experiment of Brasino (1986, unpublished Ph.D. thesis, University of Wisconsin, Madison, WI, USA) in which bromide ion was applied to two sandy soil plots grown with potatoes. On the first plot, bromide was applied to the bottom of the furrows while on the second plot, it was applied as a band over the centre of the ridges. Soil solution was collected via suction samplers at 0.9and 1.8-m depth for bromide analysis. Bromide applied to the furrow bottom leached as a wave with peaks in the subsoil at 40 to 50 days after application. Breakthrough of the ridge-applied bromide mostly took more time (flatter waves in the subsoil). The difference was explained by (a) the higher water infiltration in the furrows, (b) the higher uptake of bromide by the plant roots in the ridges and (c) the release of bromide from senescent plants later in the growing season.

\subsection{Transport of Pesticides}

The nematicide aldicarb was incorporated by rototillage into the top layer $(0.17 \mathrm{~m})$ of a field with humic sandy soil. After this, the upper part of this layer was used for making the ridges in which potatoes were planted (Smelt et al. 1981). At some times in the growing season, they measured the distribution of aldicarb and its oxidation products with depth in soil, resulting from natural rainfall. Movement of the 
substances below the furrows was distinctly deeper than that below the ridges. This was explained from surface flow of rainwater from the ridges to the furrows. This process may have been enhanced by the water-repellent nature of the humic sandy topsoil in dry condition.

After planting potatoes in rows on ridges in a field with loamy sand soil, the herbicide metolachlor was sprayed broadcast on the soil surface (Burgard et al. 1993). The field was sprinkler-irrigated in a scheme of moderate over-irrigation. Only the soil in the furrows was sampled over time, to a depth of $0.9 \mathrm{~m}$. The amount of metolachlor in the furrow soil was measured to increase in the first period of about 3 weeks after application. This showed up in all four cases: 2 years, two dosages. The highest amount of metolachlor in the furrow soil was on average 1.7 times ( $n=4 ; \mathrm{SD}=0.5$ times) the initial amount. Most likely a fraction of the herbicide deposit on the rows was surface-transported by the water to the furrows. It is remarkable that the authors did not recognise that surface transport can be expected in ridged fields.

\subsection{Main Features of the Literature Data}

In some studies, it has been measured indirectly that water flow along the soil surface from the ridges to the furrows is an important process. However, the information on the surface transport of substances from the ridges to the furrows is scarce. It is remarkable that visual observations on water flow and soil transport along the surface were only reported by a few authors. Quantitative data on the extent of water flow and substance transport along the soil surface from ridges to furrows are almost completely lacking. The result of only one relevant study is available, and it indicates that pesticide transport along the ridged soil surface can be very important. Some studies with dyes clearly illustrate the greater water flow and substance transport in the furrow soil, as compared to that in the ridge soil. Two studies report that downwards movement of anion/pesticide in the furrow soil was distinctly greater than that in the ridge soil. The consequences of the higher water flow and more extensive pesticide transport in the furrow soil are not yet clear.

\section{Procedures}

\subsection{Description of the Experimental Field}

The starting point in the present computer simulations is a detailed experiment on a potato field with ridges and furrows in the years 2000 to 2001 (Leistra and Boesten 2008). Bromide ion (as a tracer for water flow) and carbofuran (as an example pesticide) were applied to a potato field with humic sandy soil located near Roswinkel (Province of Drenthe, The Netherlands). The soil profile consisted of a humic fine sandy plough layer (0.3-m thick), with a fine sandy subsoil in which the organic matter content decreased with depth. The FAO soil classification is gleyic podzol (FAO 1988). Measurements of soil characteristics in the profile are presented in Table 1. The groundwater table fluctuated around 1-m depth. Details on the field experiment have been given by Leistra and Boesten (2008), so it is described only briefly here.

Potatoes were planted on the field on 20 April 2000 , in rows $0.75 \mathrm{~m}$ apart. The ridges above the rows with potatoes were raised with soil from the furrows to a final difference in height between the ridges and furrows of $0.20 \mathrm{~m}$. On 10 May, carbofuran (formulated as Curaterr-liquid) was sprayed broadcast on the soil surface (with ridges and furrows), using a tractormounted boom sprayer. The dosage of $4.63 \mathrm{~kg}$ carbofuran per hectare (higher than in practice to facilitate chemical analysis) was applied in $617 \mathrm{~L}$ spray liquid per hectare. Subsequently, $\mathrm{KBr}$ solution was sprayed

Table 1 Characteristics of the soil of the Roswinkel experimental field

\begin{tabular}{|c|c|c|c|c|c|}
\hline Soil layer (m) & Sand $(>50 \mu \mathrm{m} ; \%)$ & Silt $(2-50 \mu \mathrm{m} ; \%)$ & Clay $(<2 \mu \mathrm{m} ; \%)$ & Organic matter $(\%)$ & $\mathrm{pH} \mathrm{KCl}$ \\
\hline $0-0.3$ & 87.9 & 8.5 & 3.6 & 4.3 & 4.5 \\
\hline $0.3-0.5$ & 92.5 & 5.0 & 2.5 & 1.5 & 4.8 \\
\hline $0.5-1.0$ & 95.3 & 2.7 & 2.0 & 0.4 & 5.0 \\
\hline
\end{tabular}

Sand, silt and clay are given in percentage of the mineral fraction 
at a dosage corresponding to $64.7 \mathrm{~kg}$ bromide ion per hectare, also in $617 \mathrm{~L} \mathrm{ha}^{-1}$. The area sprayed was $21 \mathrm{~m}$ (boom width) $\times 100 \mathrm{~m}$.

The potato plants emerged around the 22nd of May 2000. Soil cover by the plants increased roughly linearly, until almost complete soil cover on the 10th of July. Rooting depth can be assumed to be restricted to the top $0.5 \mathrm{~m}$ of the soil profile because of the dense sand layer below that. The potatoes were harvested by the end of November but well before their leaves died-off. In the next year 2001, the field was kept fallow.

Natural rainfall was supplemented by sprinkler irrigation (in May and June 2000), and the total amount of water was measured with rain gauges. The daily values of reference crop evaporation were taken to be the average of the values calculated by KNMI $(2000,2001)$ for the weather stations at the nearest airports of Eelde and Hoogeveen. This evaporation is calculated by Makkink's method (Feddes 1987). The cumulative amounts of rainfall plus irrigation and of reference crop evaporation are given in Fig. 1. It shows that substantial amounts of water fell on the field. The cumulative reference crop evaporation shows the course of this evaporation over the seasons. The air temperature was followed via measurements. The depth of the groundwater table was measured via six filter tubes, installed before spraying of the substances.

Soil samples were taken with long tubes (length $1.0 \mathrm{~m}$; inner diameter $0.094 \mathrm{~m}$ ) at three intervals in the potato growing season. Sixteen soil cores were taken from both the ridges and furrows. Core sections

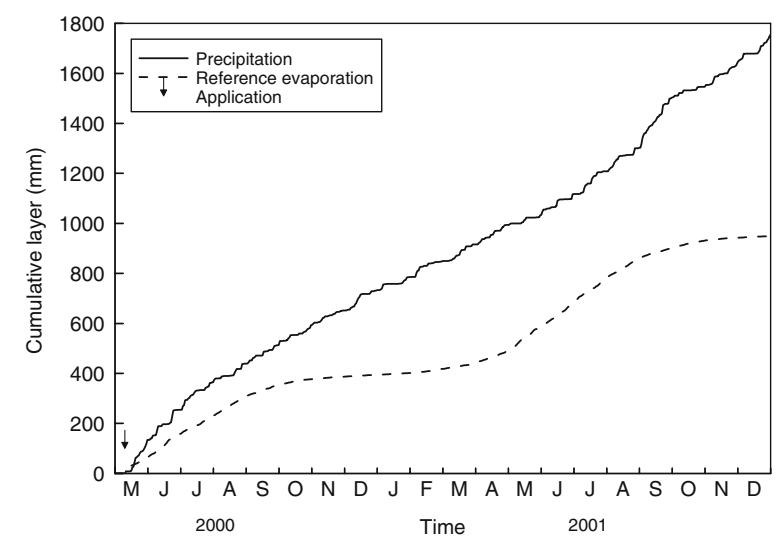

Fig. 1 Cumulative precipitation (rainfall + sprinkler irrigation) and cumulative reference evaporation for the field experiment of 0.1 or $0.2 \mathrm{~m}$ were analysed for bromide ion and carbofuran. Soil bulk density and moisture content were measured using the same samples. The results of the measurements in the soil profile were compared with the results of computer simulations (Leistra and Boesten 2010).

\subsection{Setup of the Computations}

The processes for bromide ion and carbofuran in the potato-grown ridge and furrow systems were simulated with the PEARL model, version 3.3.3. The model was described in detail by Tiktak et al. (2000, Manual) and Leistra et al. (2001, Processes). The PEARL model is coupled to the Soil Water Atmosphere Plant (SWAP) model for the description of the hydrological processes (van Dam et al. 1997). Concise descriptions of the PEARL-SWAP combination of models are presented in two studies of the risk of pesticide leaching from soils (Boesten 2004, 2007). In short, the SWAP model describes uniform water flow in the soil system using Richards' equation, and the transport of substances in the soil system is described by PEARL using the convection-dispersion equation (Leistra et al. 2001; Tiktak et al. 2000).

The ridge and furrow systems were schematised as given in Fig. 2. The top $0.1 \mathrm{~m}$ of the field soil was removed from the furrow system and added to the ridge system. This simulated the buildup of ridges with furrow material. Thus, the humic sandy top layer of the ridge system was $0.2 \mathrm{~m}$ thicker than that of the furrow system. The ridge and furrow systems each take up half of the surface area of the field.

In a field with ridges and furrows, a fraction of the water from rainfall and sprinkler irrigation can flow down the surface of the ridges to the furrows. Preliminary computations (Leistra and Boesten 2008 ) indicated that about $20 \%$ of the rainfall + irrigation falling on the ridges flowed via the soil surface to the furrows. This flow-off seemed to be restricted to the first month after application of the substances, before and just after emergence of the potato plants. In the calculations, $20 \%$ flow-off in the first month was realised by multiplying the measured rainfall + irrigation by 0.8 for the ridge system and by 1.2 for the furrow system. A fraction of the dosage of the substances can be expected to move with the surface flow of water from the ridges to the furrows. The extent of this movement was estimated 


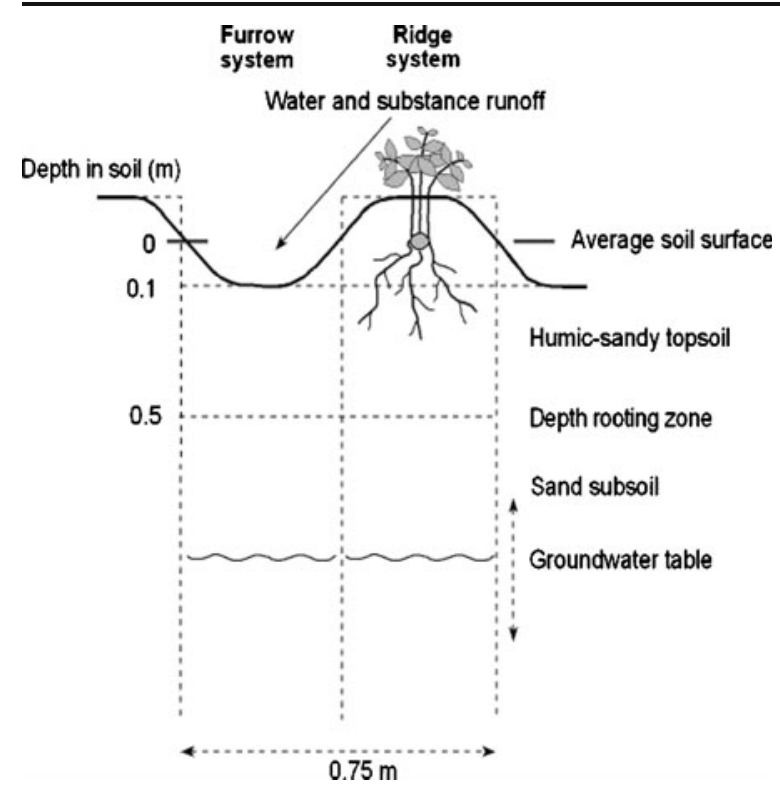

Fig. 2 Schematisation of the ridge and furrow systems

from the measurements to be $15 \%$ of the dosage (Leistra and Boesten 2008). Presuming this movement occurred soon after application of the substances, the field-averaged dosage was decreased by $15 \%$ for the ridge system and increased by $15 \%$ for the furrow system in the computations.

The ridge and furrow soil systems were simulated to a depth of $3 \mathrm{~m}$ in the field. The computation compartments were $0.02-\mathrm{m}$ thick. The properties of each soil horizon of $0.1-\mathrm{m}$ thickness were derived by interpolation and extrapolation of the measurements for the Roswinkel field (Table 1; Leistra and Boesten 2008). Water flow in the Roswinkel soil was simulated starting from the hydraulic relationships presented by Wösten et al. (2001) for a similar topsoil and subsoil. These relationships were calibrated against the measured soil moisture profiles, averaged for the whole Roswinkel field (Leistra and Boesten 2008). The depth of the groundwater table was introduced as a function of time on the basis of the measurements. The dispersion length for the spreading of substance distribution during transport with water was set at $0.05 \mathrm{~m}$. Daily minimum and maximum air temperatures were introduced for the calculation of soil temperatures by the model. The depth factor $f_{\mathrm{z}}$ for the effect of soil depth on pesticide transformation rate was taken from the Dutch Standard Scenario (Leistra and Boesten 2008).
The course of the concentration of the substances in the water phase with time (breakthrough curve) was computed for $1-\mathrm{m}$ depth in soil. This was done to illustrate the effect of distinguishing ridges and furrows on the computed leaching to the upper groundwater. The computation was carried out for both bromide ion and carbofuran in (a) the ridge system and (b) the furrow system and (c) the corresponding level field system. In the latter system, all quantities were averaged (no ridges and furrows distinguished; Leistra and Boesten 2008).

\subsection{Development of the Crop}

The development of the potato crop on the Roswinkel field was defined by using the "fixed crop cycle" option in PEARL. The plants emerged on the ridge system on 22 May 2000, and soil cover on the ridges was taken to increase linearly until full cover on 20 June. Rooting depth was taken to increase linearly from $0.2 \mathrm{~m}$ on 22 May to the final depth of $0.6 \mathrm{~m}$ on 10 July. It takes some time for the plant roots in the ridges to grow to the soil below the furrows (Fig. 2). Root development and water uptake in the furrows were assumed to start on 10 June, at zero depth. From this date on, a potato crop was assigned to the furrow system, with the soil cover increasing linearly from zero (10 June) to full cover (10 July). In the furrow system, the maximum rooting depth of $0.4 \mathrm{~m}$ was assumed to be reached on 10 July. In the top half of the rooting zone, root activity was taken to be constant with depth; in the lower half, it decreased linearly with depth to zero at the lower end of the rooting zone (Pinto 1988; Gregory and Simmonds 1992). Water uptake by the plant roots at a certain depth in soil was dependent on the pressure head of the water at that depth, as proposed for a potato crop by van Dam et al. (1997).

In the period of 10 July to 18 September, a fullgrown potato crop was simulated to be present. The height of the full-grown crop was taken to be $0.5 \mathrm{~m}$, and its Leaf Area Index was set at 4 in this period (Feddes 1987; Pinto 1988). Plant transpiration was calculated by multiplying the reference evaporation by a crop factor of 1.1 for the whole growth period (Feddes 1987). In the period of 19 September to 16 October, the green plant parts died-off linearly until no active canopy was left. The potato tubers were harvested at the end of November. The soil was kept fallow during the next year 2001 . 
After harvest of the potatoes, separate ridge and furrow systems no longer existed; thus, the computation was interrupted. The soil surface was taken to be levelled. The concentrations of the substances in the ridge and furrow systems at harvest were assigned to the corresponding layers of the post-harvest level field. The top $0.2 \mathrm{~m}$ of the ridge system was assigned to the top $0.1 \mathrm{~m}$ of the post-harvest system. The concentrations computed for the other layers were averaged (ridge $0.2-0.3-\mathrm{m}$ layer with furrow $0-0.1-\mathrm{m}$ layer gives post-harvest $0.1-0.2-\mathrm{m}$ layer, etc.). The averaged concentrations on 30 November were introduced as initial distribution of the substances in soil in the post-harvest computation.

\subsection{Input Data for the Substances}

Bromide ion was selected as a tracer for water flow because it shows minimal interactions with the soil. The ionic mass of bromide ion is $79.9 \mathrm{~g} \mathrm{~mol}^{-1}$. The vapour pressure of bromide ion was set at zero and its solubility in water at $10^{5} \mathrm{mg} \mathrm{L}^{-1}$ (an arbitrary high value). The coefficient for diffusion of bromide ion in water (Lide 1999), translated to $20^{\circ} \mathrm{C}$, was taken to be $1.6 \times 10^{-4} \mathrm{~m}^{2} \mathrm{day}^{-1}$. Adsorption of bromide ion to soil was set at zero. The half-life of transformation in soil was taken to be $10^{5}$ days (arbitrary high value). The concept of the Transpiration Stream Concentration factor (TSCF) for uptake by plant roots (Briggs et al. 1982) does not hold for ionic species. As there is no alternative in the model and as no quantitative information is available, TSCF was set at 0.5 .

Physico-chemical properties of carbofuran were collected from the literature and from registration sources (Leistra and Boesten 2010). Different values are stated for the vapour pressure, in a range of moderate to low values. A vapour pressure of $0.1 \mathrm{mPa}$ at $20^{\circ} \mathrm{C}$ was selected for input in the model. Solubility in water (about $320 \mathrm{mg} \mathrm{L}^{-1}$ at $20^{\circ} \mathrm{C}$ ) and octanol/water partitioning $\left(\log \left(P_{\text {ow }}\right)\right.$ about 1.6 at $20^{\circ} \mathrm{C}$ ) point to intermediate polarity of the carbofuran molecules. The coefficient for diffusion of carbofuran in air at the reference temperature $\left(20^{\circ} \mathrm{C}\right)$ was estimated to be $0.44 \mathrm{~m}^{2}$ day $^{-1}$, using the FSG method described by Tucker and Nelken (1982). Using the method of Hayduk and Laudie described by Tucker and Nelken (1982), the diffusion coefficient of carbofuran in water was estimated to be $0.44 \times 10^{-4} \mathrm{~m}^{2}$ day $^{-1}$.
The adsorption of carbofuran to Roswinkel topsoil was measured in the laboratory (Leistra and Boesten 2008). The Freundlich coefficient $K_{\mathrm{F}}$ (at $15^{\circ} \mathrm{C}$ ) was measured to be $0.77 \mathrm{~L} \mathrm{~kg}^{-1}$, and the exponent was 0.83 . The value of coefficient $K_{\text {om }}$ for the adsorption of carbofuran to soil organic matter was calculated to be $16 \mathrm{~L} \mathrm{~kg}^{-1}$. This value is within the range of values reported in the literature (Leistra and Boesten 2008), and it indicates that the adsorption of carbofuran to soils is moderate to weak. The rate of transformation of carbofuran in the Roswinkel soil had to be estimated from the measurements in the field. Leistra and Boesten (2008) estimated the half-life for the transformation of carbofuran in the soil in the growing season to be 35 days. This value was introduced into the computations as the reference half-life value (topsoil; $15^{\circ} \mathrm{C}$; moisture condition at $\mathrm{pF}=2$ ). The uptake of carbofuran by the roots of the potato crop was described according to Briggs et al. (1982). They derived a relationship between the TSCF and the $\log \left(P_{\text {ow }}\right)$ value for octanol/water partitioning of the compound. Using this relationship, the TSCF value for carbofuran was calculated to be 0.78 (potentially high uptake).

\section{Results of the Computations}

\subsection{Water Balance}

The water balances of the soil-plant systems in the period 10 May (substance applications) to 30 November (potato harvest) are given in Table 2. The higher infiltration of $76 \mathrm{~mm}$ in the furrows is brought about by $38 \mathrm{~mm}$ of water flowing along the surface

Table 2 Items of the water balance of the ridge and furrow systems of the potato field in the period 10 May 2000 (application of the substances) to 30 November 2000 (harvest of the potato crop)

\begin{tabular}{lcc}
\hline Item of the water balance & \multicolumn{2}{l}{ Water layer $(\mathrm{mm})$} \\
\cline { 2 - 3 } & Ridge system & Furrow system \\
\hline Infiltration & 614 & 690 \\
Uptake by plants & 261 & 208 \\
Evaporation form soil & 138 & 175 \\
Difference in storage & -22 & -21 \\
Outflow & 237 & 328 \\
\hline
\end{tabular}


from the ridges. Water uptake by the plants from the ridge soil was higher because root activity was higher than in the furrow soil, especially in the first part of the growing period. Water uptake from both systems equalled potential transpiration, so there was no water shortage. The presence of a crop strongly reduces water evaporation from the covered soil surface (van Dam et al. 1997). The ridge soil was covered earlier by the canopy than the furrow soil. Consequently, cumulative evaporation from the ridge soil was lower than that from the furrow soil. There was some decrease in water storage in the soil profiles because the volume fractions of water at harvest were somewhat lower than those at the start. The overall result was that water outflow from the furrow system was substantially higher than that from the ridge system.

\subsection{Breakthrough of Bromide Ion}

Figure 3 shows the results of the computations of bromide ion breakthrough at 1-m depth in the field for the ridge and furrow systems, as compared with the results for the corresponding level field system. Breakthrough of bromide ion from the furrow system already started within a month after application. The peak concentration of $36 \mathrm{mg} \mathrm{dm}^{-3}$ was reached at the end of June 2000. After that, the breakthrough concentration decreased gradually to $18 \mathrm{mg} \mathrm{dm}^{-3}$ at harvest (30 November; end of furrow system). Then

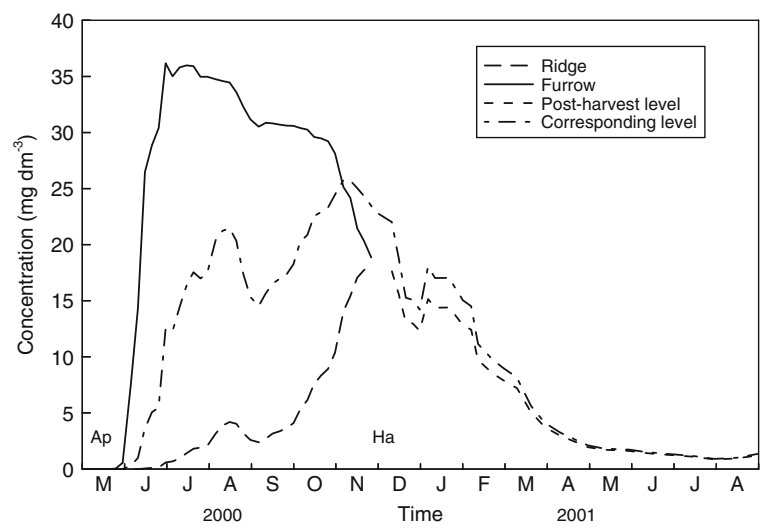

Fig. 3 Concentrations of bromide ion in the water phase passing at $1-\mathrm{m}$ depth in the field (breakthrough curve) computed for (1) ridge system until harvest, (2) furrow system until harvest, (3) post-harvest level field (follow-up of ridges and furrows) and (4) corresponding level field. $A p=$ application on 10 May; $H a=$ harvest on 30 November the peak of the distribution of bromide ion was computed to be at a depth of $1.35 \mathrm{~m}$ in the furrow system. Breakthrough of bromide ion from the ridge system (Fig. 3) started at the end of June 2000, and the concentration increased to a maximum of $18 \mathrm{mg} \mathrm{dm}^{-3}$ at harvest time. Then the peak of the distribution of bromide ion was computed to be at $0.95-\mathrm{m}$ depth in the ridge system. Breakthrough of bromide ion computed for the post-harvest level field (follow-up of ridges and furrows) shows that the concentration at $1-\mathrm{m}$ depth decreased gradually to low values in the summer of 2001 .

The results of the computation of bromide ion breakthrough from the corresponding level field are given in Fig. 3, for comparison. Breakthrough from the top metre of this averaged field system started in the beginning of June 2000. The first part of the breakthrough curve was roughly halfway between those for the ridge and furrow systems. A peak concentration of $26 \mathrm{mg} \mathrm{dm}^{-3}$ was reached in the beginning of November 2000. After this, the breakthrough concentration decreased gradually to a low level in the summer of 2001.

The only sink term for bromide ion in the soil systems was uptake by the crop roots. Uptake from the ridge system was computed to be $34.7 \%$ of the net dosage (field dosage minus runoff). For the furrow system, plant uptake was computed to be $3.9 \%$ of the gross dosage (field dosage plus runoff). Much of the bromide in the furrow soil moved down the top layer before the root systems had developed there.

The maximum concentration of bromide ion leaching from the ridge system was lower than that leaching from the furrow system. This difference was caused by three factors. Firstly, the net dosage of bromide ion on the ridges was lower than the gross dosage on the furrows because of runoff. Secondly, more bromide was taken up from the more intensively rooted ridge soil than from the furrow soil. Thirdly, the ridge system was $1.1-\mathrm{m}$ long, compared to $0.9 \mathrm{~m}$ for the furrow system (breakthrough depth of $1.0 \mathrm{~m}$ in the field), which caused more hydrodynamic dispersion in the former.

The concentrations of bromide ion computed for the outflow at $1-\mathrm{m}$ depth in the field in September 2000 can be compared with the soil measurements for the 0.8 - to $1.0-\mathrm{m}$ soil layer halfway that month (Leistra and Boesten 2008, 2010). The average outflow concentration of $17 \mathrm{mg} \mathrm{dm}^{-3}$ for the ridge 
and furrow systems, multiplied by the saturated volume fraction of water of $0.31 \mathrm{dm}^{3} \mathrm{dm}^{-3}$, gives a bromide ion concentration in soil of $5.3 \mathrm{mg} \mathrm{dm}^{-3}$. This value for $1.0-\mathrm{m}$ depth is close to the average soil concentration of $7.7 \mathrm{mg} \mathrm{dm}^{-3}$ measured in the 0.8 - to $1.0-\mathrm{m}$ layer of the soil.

\subsection{Breakthrough of Carbofuran}

The concentration of carbofuran computed to break through from the furrow system at 1-m depth in the field increased rapidly in June 2000 (Fig. 4). A maximum concentration of $72 \mu \mathrm{g} \mathrm{dm}^{-3}$ was reached in mid August and a second maximum of $74 \mu \mathrm{g} \mathrm{dm}^{-3}$ in the beginning of November 2000. At harvest time, the peak of the distribution of carbofuran in furrow soil was at $0.85-\mathrm{m}$ depth (not shown here). Carbofuran in the ridge soil system did not reach 1-m depth in the period up to harvest (all values zero in Fig. 4). The peak of the distribution of carbofuran was at $0.25-\mathrm{m}$ depth in the ridge soil at harvest time (not shown here). The computation for the post-harvest level field (follow-up of ridges and furrows) resulted in a tail of the breakthrough curve (Fig. 4). The concentration in water at 1-m depth decreased gradually to a comparatively low level in the autumn of 2001.

The concentrations of carbofuran in the water flowing at 1-m depth in soil, computed for the corresponding level field system, are also shown in Fig. 4. Breakthrough started at the end of October 2000, and a

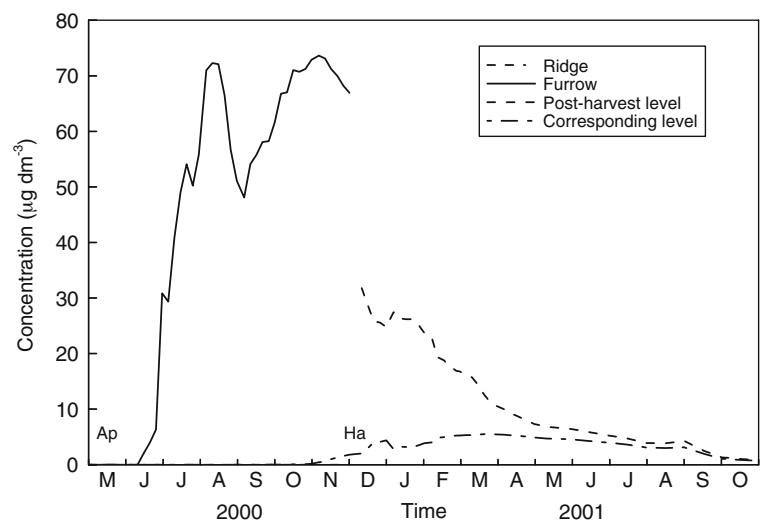

Fig. 4 Concentrations of carbofuran in the water phase passing at $1-\mathrm{m}$ depth in the field (breakthrough curve) computed for (1) ridge system until harvest (all values zero), (2) furrow system until harvest, (3) post-harvest level field (follow-up of ridges and furrows) and (4) corresponding level field. $A p=$ application on 10 May; $H a=$ harvest on 30 November
Table 3 Computed material balances of carbofuran in the ridge and furrow systems for the period 10 May 2000 (application of the substances) to 30 November 2000 (harvest of the potato crop)

\begin{tabular}{lcc}
\hline Item of the material balance & \multicolumn{2}{c}{ Percentage of the dosage } \\
\cline { 2 - 3 } & Ridge system & Furrow system \\
\hline Transformation in soil & 85.4 & 89.3 \\
Uptake by plant roots & 12.7 & 5.8 \\
Left in soil system & 1.9 & 4.9
\end{tabular}

maximum concentration of $5.5 \mu \mathrm{g} \mathrm{dm}{ }^{-3}$ was reached in March 2001. After this, the breakthrough concentration of carbofuran decreased gradually to a comparatively low level in the autumn of 2001.

The material balances computed for carbofuran in the ridge and furrow systems (3-m deep) in the period up to harvest time are presented in Table 3. The highest percentage of the pesticide dosage was transformed in the soil. Uptake by plant roots from the ridge system was computed to be higher than that from the furrow system because of the more intensive rooting and slower pesticide movement out of the root zone in the former. Leaching in the ridge system below 1-m depth in the field was computed to be negligible, while leaching in the furrow system below this depth was $1.5 \%$ of the dosage. Volatilisation from the soil surface was computed to be negligible.

The computed breakthrough concentration of carbofuran at 1-m depth in September 2000 can be compared with the soil measurements in the 0.8 - to $1.0-\mathrm{m}$ layer halfway in that month (Leistra and Boesten 2008, 2010). A representative outflow concentration of $53 \mu \mathrm{g} \mathrm{dm}{ }^{-3}$ was computed for the furrow system in September. In the water-saturated subsoil, with a volume fraction of water of $0.31 \mathrm{dm}^{3}$ $\mathrm{dm}^{-3}$, this outflow concentration corresponds to a soil concentration of $16.4 \mu \mathrm{g} \mathrm{dm}^{-3}$. The concentration of carbofuran measured in the $0.8-$ to $1.0-\mathrm{m}$ soil layer of the furrow soil was on average $22 \mu \mathrm{g} \mathrm{dm}^{-3}$. The outflow concentration (1-m depth) for the ridge system in September was computed to be nil, which is also nil for the concentration on soil basis. This can be compared with the comparatively low average concentration of $1 \mathrm{\mu g} \mathrm{dm}^{-3}$ measured for the 0.8 - to $1.0-\mathrm{m}$ layer in the ridge soil. So the computed concentrations correspond to the level of the measured concentrations. 


\section{General Discussion}

In the literature, there are several indications that precipitation water can flow along the soil surface from the ridges to the furrows in agricultural fields. Most of the measurements deal with the volume fraction of water, which is often higher in the furrow soil than in the ridge soil. Surface flow mainly occurs at high precipitation rates (rainfall, sprinkler irrigation) on bare soil surfaces. Comparatively little attention has been paid to the surface transport of soil material and sprayed pesticides from the ridges to the furrows.

There is a lack of information on the amount of water that can flow from the ridges to the furrows in different conditions; direct measurements could not be found. Only little quantitative information is available on the amount of sprayed substances that can be surface-transported from the ridges to the furrows. Such transport can be estimated by measuring the amounts of the substances in the ridge and furrow soils in the first period after application (as long as no leaching occurred). The two estimates available now are highly different: $70 \%$ of the dosage (Burgard et al. 1993) and 15\% of the dosage (Leistra and Boesten 2008).

In the leaching computations for the separate ridge and furrow systems, the inert tracer bromide ion shows the expected pattern. Leaching from the furrow system occurs earlier and at higher concentrations than the leaching from the ridge system. The somewhat lower leaching concentrations for the ridge system result from

1. Surface flow of water to the furrows

2. Surface transport of bromide to the furrows

3. More uptake of water and bromide ion by the plant roots in the ridge soil

4. Somewhat more hydrodynamic dispersion in the longer ridge soil system (1.1 m versus $0.9 \mathrm{~m}$ for the furrow system)

As bromide ion is not transformed in soil, the transport time does not have an effect on the amount of breakthrough. The breakthrough pattern for the corresponding level field is roughly midway between the patterns for the furrow and ridge systems.

The example pesticide carbofuran shows a very large difference in leaching computed for the ridge and furrow systems. The causes of the much higher leaching from the furrow systems are

1) Surface flow of water from the ridges to the furrows

2) Surface transport of pesticide from the ridges to the furrows

3) The comparatively short pesticide transport time in the furrow system

4) Less uptake of water and pesticide by plant roots in the furrow system

5) Less hydrodynamic dispersion in the shorter furrow system

Four of these causes (numbers1, 2, 4 and 5) are the same as for bromide ion, and they have only a small to moderate effect on the leaching pattern. The main cause of the large difference in leaching for carbofuran is the shorter transport time (and thus transformation time) in the furrow system, as compared to that in the ridge system. In the furrow system, the soil zone with highest bioactivity is $0.2-\mathrm{m}$ thinner, while the rate of water flow is about 1.5 times as high as that in the ridge system.

The present study shows that the risk of leaching of pesticides sprayed on ridge-furrow fields is higher than that from corresponding level fields. It is desirable to account for this higher risk in the pesticide evaluation procedures. However, this requires the development of scenarios that are representative for practical situations. For this purpose, more quantitative experimental data are needed, especially on the extent of surface transport of water and pesticide from the ridges to the furrows, under a range of practical conditions.

Acknowledgement This study was carried out in the framework of Research Theme BO-06-10: "Risk assessment methodology for the registration of plant protection products" of the Dutch Ministry for Agriculture, Nature and Food Quality.

Open Access This article is distributed under the terms of the Creative Commons Attribution Noncommercial License which permits any noncommercial use, distribution, and reproduction in any medium, provided the original author(s) and source are credited.

\section{References}

Agassi, M., \& Levy, G. J. (1993). Effect of the dyked furrow technique on potato yield. Potato Research, 36, 247-251.

Agassi, M., Shainberg, I., Warrington, D., \& Ben-Hur, M. (1989). Runoff and erosion control in potato fields. Soil Science, 148, 149-154. 
Benjamin, J. G., Blaylock, A. D., Brown, H. J., \& Cruse, R. M. (1990). Ridge tillage effects on simulated water and heat transport. Soil \& Tillage Research, 18, 167-180.

Boesten, J. J. T. I. (2004). Influence of dispersion length on leaching calculated with PEARL, PELMO and PRZM for FOCUS groundwater scenarios. Pest Management Science, 60, 971-980.

Boesten, J. J. T. I. (2007). Simulation of pesticide leaching in the field and in zero-tension lysimeters. Vadose Zone Journal, 6, 793-804.

Briggs, G. G., Bromilow, R. H., \& Evans, A. A. (1982). Relationships between lipophilicity and root uptake and translocation of non-ionised chemicals by barley. Pesticide Science, 13, 495-504.

Burgard, D. J., Koskinen, W. C., Dowdy, R. H., \& Cheng, H. H. (1993). Metolachlor distribution in a sandy soil under irrigated potato production. Weed Science, 41, 648-655.

Cooley, E. T., Lowery, B., Kelling, K. A., \& Wilner, S. (2007). Water dynamics in drip and overhead sprinkler irrigated potato hills and development of dry zones. Hydrological Processes, 21, 2390-2399.

Dekker, L. W., \& Ritsema, C. J. (1996). Uneven moisture patterns in water repellent soils. Geoderma, 70, 87-99.

European Soil Bureau Network (2005). Soil Atlas of Europe. L-2995 Luxembourg: European Commission, Office for Official Publications of the European Communities.

Eurostat (2009). Agricultural products. Brussels: European Commission, Eurostat. http://epp.eurostat.ec.europa/portal/ page/agriculture/data/main_tables.

FAO (1988). FAO-UNESCO soil map of the world. Revised Legend. World Resources Report 60. Rome: Food and Agricultural Organisation of the United Nations.

Feddes, R. A. (1987). Crop factors in relation to Makkink reference-crop evapotranspiration. In J. C. Hooghart (Ed.), Evaporation and weather. Proceedings and information 39 (pp. 33-45). The Hague: TNO Committee on Hydrological Research.

Flury, M. (1996). Experimental evidence of transport of pesticides through field soils-a review. Journal of Environmental Quality, 25, 25-45.

FOCUS (2000). FOCUS groundwater scenarios in the EU review of active substances. Report of the FOCUS Groundwater Scenarios Workgroup. EC Document Reference Sanco/321/2000 rev. 2, 202 pp. Brussels: European Commission.

Gregory, P. J., \& Simmonds, L. P. (1992). Water relations and growth of potatoes. In P. Harris (Ed.), The potato crop. The scientific basis for improvement (pp. 214-246). London: Chapman \& Hall.

Huaccho, L., \& Hijmans, R. J. (1999). A global geo-referenced database of potato distribution for 1995-1997. International Potato Center (CIP): Lima.

Jefferies, R. A., \& MacKerron, D. K. L. (1985). Stemflow in potato crops. Journal of Agricultural Science, 105, 205-207.

Keizer, J. J., Doerr, S. H., Malvar, M. C., Ferreira, A. J. D., \& Pereira, V. M. F. G. (2007). Temporal and spatial variations in topsoil water repellency throughout a croprotation cycle on sandy soil in north-central Portugal. Hydrological Processes, 21, 2317-2324.

KNMI (2000). Maandoverzicht neerslag en verdamping in Nederland (Monthly survey of precipication and evapora- tion in the Netherlands). De Bilt: Royal Netherlands Meteorological Institute.

Kouwenhoven, J. K. (1978). Ridge quality and potato growth. Netherlands Journal of Agricultural Science, 26, 288-303.

Kung, K. J. S. (1988). Ground truth about water flow pattern in a sandy soil and its influences on solute sampling and transport modeling. In P. J. Wierenga \& D. Bachelet (Eds.), International conference and workshop on the validation of flow and transport models for the unsaturated zone (pp. 224-230). Las Cruces NM: New Mexico State University.

Kung, K. J. S. (1990a). Preferential flow in a sandy vadose zone: 2. Mechanisms and implications. Geoderma, 46, 5971.

Kung, K. J. S. (1990b). Influence of plant uptake on the performance of bromide tracer. Soil Science Society of America Journal, 54, 975-979.

Leistra, M. (1985). Computer simulations of the transport of pesticides with nonuniform water flow in greenhouse soil. Soil Science, 140, 161-169.

Leistra, M. (2005). Estimating input data for computations on the volatilisation of pesticides from plant canopies and competing processes. Alterra report 1256. Wageningen: Alterra, Wageningen University and Research Centre.

Leistra, M., \& Boesten, J. J. T. I. (2008). Movement of bromideion and carbofuran in the humic sandy soil of a potato field with ridges and furrows. Measurements in the field and computations with the PEARL model. Alterra-rapport 1750. Wageningen: Alterra, Wageningen University and Research Centre.

Leistra, M., \& Boesten, J. J. T. I. (2010). Measurement and computation of movement of bromide ions and carbofuran in ridged humic-sandy soil. Archives of Environmental Contamination and Toxicology. doi:10.1007/s00244-0099442-4.

Leistra, M., van der Linden, A. M. A., Boesten, J. J. T. I., Tiktak, A., \& van den Berg, F. (2001). PEARL model for pesticide behaviour and emissions in soil-plant systems. Description of the processes in FOCUS PEARL v 1.1.1. Alterra-rapport 013; RIVM report 711401009 . Wageningen, The Netherlands: Alterra, Green World Research.

Lide, D. R. (Ed.). (1999). CRC handbook of chemistry and physics (80th ed.). Boca Raton: CRC Press.

Pinto, P. J. C. A. (1988). Computer simulation modeling of the growth and development of the potato crop under different water regimes. Ph.D. Dissertation. Davis CA: University of California.

Robinson, D. (1999). A comparison of soil-water distribution under ridge and bed cultivated potatoes. Agricultural Water Management, 42, 189-204.

Saffigna, P. G., Tanner, C. B., \& Keeney, D. R. (1976). Nonuniform infiltration under potato canopies caused by interception, stemflow and hilling. Agronomy Journal, 68, 337-342.

Smelt, J. H., Schut, C. J., Dekker, A., \& Leistra, M. (1981). Movement and conversion of aldicarb and its oxidation products in potato fields. Netherlands Journal of Plant Pathology, 87, 177-191.

Starr, G. C., Cooley, E. T., Lowery, B., \& Kelling, K. (2005). Soil water fluctuations in a loamy sand under irrigated potato. Soil Science, 170, 77-89. 
Tiktak, A., van den Berg, F., Boesten, J. J. T. I., van Kraalingen, D., Leistra, M., \& van der Linden, A. M. A. (2000). Manual of FOCUS PEARL version 1.1.1. RIVM report 711401008 , Alterra report 28. Bilthoven, The Netherlands: National Institute of Public Health and the Environment.

Tucker, W. A., \& Nelken, L. H. (1982). Diffusion coefficients in air and water. In: W. J. Lyman, W. F. Reehl, \& D. H. Rosenblatt (Ed.), Handbook of chemical property estimation methods. Environmental behavior of organic compounds (pp. 1-25). New York: McGraw-Hill.

van Dam, J. C., Huygen, J., Wesseling, J. G., Feddes, R. A., Kabat, P., van Walsum, P. E. W., et al. (1997).
SWAP version 2.0. Theory. Simulation of water flow, solute transport and plant growth in the Soil-WaterAtmosphere-Plant environment. Wageningen: Department of Water Resources, Wageningen Agricultural University. Report 71.

Wösten, J. H. M., Veerman, G. J., de Groot, W. J. M., \& Stolte, J. (2001). Waterretentie - en doorlatendheidskarakteristieken van boven- en ondergronden in Nederland: de Staringreeks (Water retention and conductivity characteristics of topsoils and subsoils in The Netherlands: the Staring Series). Wageningen: Alterra. Alterra Rapport 153 . 